\title{
COMPARISON BETWEEN HEAT PUMP AND ELECTRIC HEATER FOR DRYING ONION SLICES
}

\author{
Abdelwahab N. Allam *, M. M. Nasr, Mohamed R. O. Ali \\ Mechanical Power Engineering and Energy Department, Faculty of Engineering, Minia University, 61519 Minia, Egypt \\ * corresponding author E-mail: abdelwahab2011@mu.edu.eg
}

\section{ABSTRACT}

Food and agricultural products require drying to ensure that their nutritional value is unaffected during handling and storage. Numerous techniques of drying are in use. This work compares drying with a heat pump dryer (HPD) and an electric heater dryer (EHD) for Egyptian onion slices. Empirical equations were obtained to calculate the change of moisture over time. This comparison used the following criteria: moisture content, energy consumption, moisture extraction rate, specific moisture extraction rate, and drying time. The onions were cut into slices $3 \mathrm{~mm}$ thick and 15 to 20 $\mathrm{mm}$ long. The slices were dried at temperatures of 50,60 , and $70{ }^{\circ} \mathrm{C}$ and drying air velocities of 0.2 , 0.3 , and $0.4 \mathrm{~m} / \mathrm{s}$. The results indicated that a drying of $83 \%$ to $26 \%$ moisture content on a wet basis or from $4.88 \mathrm{gm}_{w a t e r} / \mathrm{gm}_{\mathrm{dm}}$ to $0.35 \mathrm{gm}_{w a t e r} / \mathrm{gm}_{\mathrm{dm}}$ on a dry basis was achieved in one stage in the multiple stages of drying. The experiments showed that the energy savings resulting from using HPD was $22.2 \%$. The best value for the $\mathrm{R}^{2}$ of moisture content change over time was obtained by drying Egyptian onion slices according to different drying models for EHD and HPD.

Keywords: Heat pump dryer, onion slices drying, hot-air drying, drying temperature, moisture content

\section{INTRODUCTION}

Drying is an energy-intensive process, in which water is evaporated from a substance. The main objective of drying is to obtain a dried product at the highest quality and lowest cost, as well as at the maximum productivity. Onions are among of the most important crops in all countries, and they rank third in global production among vegetables $[1,2]$. They are widely exported and imported, and if they are to be supplied for long periods and transported at the lowest prices, it is very important to dry them. Industrial drying can

Received:14 Novamber,2020, Accepted:20 March, 2021 be conducted within a single stage through a multi-stage process, depending upon the drying temperature used and the moisture content of the object [3].

HPD is among the most recent and most advanced techniques for drying, joining other methods such as hot air, gas, vacuum, steam, irradiation, solar drying, and others [4].

HPD is a common technology for lowering energy consumption of industrial processes [5]. Around 7\% of drying in 1988 was performed by industrial heat pumps (HPs) [6]. 
Vol. 41, No.2. July 2022

\begin{tabular}{|c|c|c|c|}
\hline \multicolumn{4}{|c|}{ Nomenclature } \\
\hline A & Cross sectional area of the duct, $\mathrm{m}^{2}$ & MR & Moisture ratio \\
\hline $\mathrm{C}_{\mathrm{p}}$ & Specific heat, $\mathrm{kJ} / \mathrm{kg} \cdot \mathrm{K}$ & $\dot{m}$ & Mass flowrate, $\mathrm{kg} / \mathrm{s}$ \\
\hline $\mathrm{COP}$ & Coefficient of performance & $\mathrm{P}$ & Pressure, kpa \\
\hline DR & Drying Rate, $\mathrm{gm}_{\text {water }} / \mathrm{gm}_{\mathrm{dm} . \mathrm{s}}$ & $\dot{Q}$ & Amount of heat transferred rate, $\mathrm{kw}$ \\
\hline $\mathrm{dt}$ & Difference in time, $\mathrm{s}$ & $\mathrm{RH}$ & Relative humidity $(\%)$ \\
\hline$h$ & Enthalpy, $\mathrm{kJ} / \mathrm{kg}$ & SEC & $\begin{array}{l}\text { Specific energy consumption, } \\
\mathrm{kW} \cdot \mathrm{h} / \mathrm{kg}\end{array}$ \\
\hline hp & Horse power & SMER & $\begin{array}{l}\text { Specific moisture extraction rates, } \\
\mathrm{kg} / \mathrm{kW} \cdot \mathrm{h}\end{array}$ \\
\hline $\mathrm{K}$ & Drying constant & $\mathrm{T}$ & Temperature, ${ }^{\circ} \mathrm{C}$ \\
\hline $\mathrm{MC}$ & Moisture content, $\mathrm{gm}_{\text {water }} / \mathrm{gm}_{\mathrm{dm}}$ & $\mathrm{V}$ & Velocity, $\mathrm{m} / \mathrm{s}$ \\
\hline M & Mass of matter, $\mathrm{kg}$ & $\dot{W}$ & Power, kw \\
\hline MER & Moisture extraction rates, $\mathrm{kg} / \mathrm{s}$ & & \\
\hline
\end{tabular}

\begin{tabular}{|llll|}
\hline \multicolumn{2}{|l}{ Abbreviation } & & \\
EHD & Electric heat drying or dryer & SEE & Standard error of estimation \\
HP & Heat pump & PID & Proportional integral derivative \\
HPD & Heat pump drying or dryer & & \\
\hline
\end{tabular}

\begin{tabular}{|llll|}
\hline \multicolumn{2}{ll}{ Subscripts } & evap & Evaporator \\
air & Air & f & Fan \\
comp & Compressor & in & Inlet \\
cond & Condenser & out & Outlet \\
D & Drying & Ref & Refrigerant \\
$\mathrm{db}$ & Dry basis & $\mathrm{t}$ & Time \\
$\mathrm{dm}$ & Dry matter & wb & Wet basis \\
$\mathrm{dry}$ & Dryer & ws & Whole system \\
$\mathrm{E}$ & equilibrium & & \\
\hline
\end{tabular}


Vol. 41, No.2. July 2022

\section{Greek symbols}

P Density $\left(\mathrm{kg} / \mathrm{m}^{3}\right)$

$\eta \quad$ Efficiency

$\Omega \quad$ Specific humidity $\left(\mathrm{kg}_{\mathrm{m}} / \mathrm{kg}_{\mathrm{da}}\right)$

HPD is performed with a HP and works with a vapor compression cycle consists of an evaporator, compressor, expansion valve, and condenser with a drying unit. To absorb moisture from materials hot, dry air is required. When the hot air leaves the condenser and enters the drying chamber, it acquires moisture from the product to be dried.

Among the factors that affect the performance of the drying system include the air temperature, relative air humidity, drying air velocity, extraction rate of moisture content (MER), the specific MER (SMER), the coefficient of performance (COP) of the cycle drying time, energy efficiency and exergy efficiency (or the economic analysis of the system), industrial installation and operating costs, the power required for running the system, and the product quality $[3,6]$. Comparing the HPD against an electrical resistance dryer indicates in an energy saving of $\sim 40 \%$ where COP of heat pump was between 2.56 and 2.68, as determined by an experimental study conducted by Queiroz et al. [7].

A comparison between common traditional drying methods and HPD using parameters such as SMER, drying efficiency, operating temperature range, operating relative humidity range, capital cost, and running cost is given in Table $1[6,8]$. Here, it is clearly indicated that the HPD is the most efficient drying system in relation to SMER, running cost, and drying efficiency.

Many types of HPs are available for use in drying. Among these are ground source HPD systems. Several HPD models have already received study in relation to the type of application, product material, drying chamber configuration, closed cycle and open cycle drying model, and hybrid HPD systems [9].

Table 1. Comparison between (HPD) and traditional drying methods $[\mathbf{6}, \mathbf{8}]$

\begin{tabular}{|c|c|c|c|}
\hline Parameter & Hot air drying (EHD) & Vacuum drying & Heat pump dryer \\
\hline $\begin{array}{l}\text { Operating temperature range } \\
\qquad\left({ }^{\circ} \mathrm{C}\right)\end{array}$ & $40-90$ & $30-60$ & $10-65$ \\
\hline Operating \% RH range & Variable & Low & Wide range \\
\hline SMER $(\mathrm{kg} / \mathbf{k W} \cdot \mathbf{h})$ & $0.12-1.28$ & $0.72-1.2$ & $1.0-4.0$ \\
\hline Drying efficiency & $35-40$ & $\leq 70$ & 95 \\
\hline Capital cost & Low & High & Moderate \\
\hline Running cost & High & Very high & Low \\
\hline
\end{tabular}


Sarsavadia et al. [10] developed a batchtype experimental dryer for onions and reported that onions are usually dried to a $7 \%$ or less wet basis from the original wet content to be stored and treated effectively. Fatouh et al. [11] experimentally studied the drying properties of different herbs using an electric heater as an auxiliary device. They concluded that air drying at $55^{\circ} \mathrm{C}$ with air at a velocity of $2.7 \mathrm{~m} / \mathrm{s}$ achieved the highest drying rate. Effects of drying temperature and sample mass were studdied [12], date survey in the field of air source heat pump[13, 14]

Ceylan et al. [15] experimentally studied the performance of a HPD as a single stage through a multi-stage process for kiwis, avocados, and bananas where initial moisture contents of the kiwi, avocado, and banana were $4.31,1.51$, and $4.71 \mathrm{gm}_{\text {water }} / \mathrm{gm}_{\mathrm{dm}}$ (81.17\%, 60.16\%, and $82.49 \%$ wet basis) which were dried to $0.75,0.35$, and 0.5 $\mathrm{gm}_{\text {water }} / \mathrm{gm}_{\mathrm{dm}}(42.85 \%, 25.9 \%$, and $33.3 \%$ wet basis). The range of drying velocity considered was 0.03 to $0.39 \mathrm{~m} / \mathrm{s}$. Also, they evaluated the experimental models Newton, Page, Modified Page, Henderson and Papis, Logarithmic, Wang, and Singh and found that the Page model had the best $\mathrm{R}^{2}$, of 0.99982 , and the lowest standard error of estimation (SEE) of 0.00384 for an avocado. Arslan and Ozcan [16] experimentally studied the effects of sun, oven, and microwave drying on the quality of onion slices with temperatures of $50^{\circ} \mathrm{C}-70^{\circ} \mathrm{C}$. They found that the Page and Modified Page models give high $\mathrm{R}^{2}$ values, ranging between 0.994 and 0.999 . Mota et al. [17] experimentally analyzed the effects of drying temperature on the chemical composition of the onion, including its moisture content, sugar content, ash, crude fiber, crude protein, fat, acidity, and vitamin
C. They found that changing the drying temperature from $30^{\circ} \mathrm{C}$ to $60^{\circ} \mathrm{C}$ reduced the drying time from 7 to $2 \mathrm{~h}$.

EL-Mesery and Mwithiga [18] conducted an experimental comparison between a gasfired hot-air dryer and an electrically heated hot-air dryer on onion slices. They set drying air temperatures of $50^{\circ} \mathrm{C}, 60^{\circ} \mathrm{C}$, and $70^{\circ} \mathrm{C}$ and $0.5,1.0$, and $2.0 \mathrm{~m} / \mathrm{s}$ as the drying air velocity. The results showed that the value for SEC is proportional to the air velocity and is inversely proportional to the drying temperature of both dryers.

Singh et al. [19] experimentally investigated HPD and solar-assisted HPD modes on bananas and concluded that the solar-assisted HPD system worked better in all respects. Sasongko et al. [20] studied the effects of drying temperature and relative humidity on the quality of dried onion slices and showed that the optimum conditions for onion slice drying were achieved at $49.6^{\circ} \mathrm{C}$ and a relative humidity of $0.65 \%$. Bahnasawy et al. [21] studied the physical and mechanical properties of some Egyptian onion cultivars and found that the initial moisture content of the types of Egyptian onion was $83 \%$ wet basis.

It can be concluded that the drying velocity can range from 0.03 to $3 \mathrm{~m} / \mathrm{s}$, and the optimum velocity depends on the nature of the material to be dried, as well as the technology used for drying and differs from application to another, for onion it is small up to 0.4 or 0.5 $\mathrm{m} / \mathrm{s}$. The optimum drying temperature for the onion is between $50^{\circ} \mathrm{C}$ and $70^{\circ} \mathrm{C}$ for singlestage drying, depending on the initial MC. In this study, the effects of drying temperature and velocity on drying properties using EHD and HPD were investigated experimentally to 
Vol. 41, No.2. July 2022

compare between the techniques. The results are used to generate the best fit for the empirical drying equations for Egyptian onions.

In the following section, the governing equation of the HPD will be investigated to calculate the performance of the drying system.

\section{THEORETICAL ANALYSIS}

Figure 1 shows a schematic of the complete system of the HPD. The heat transfer rate can be calculated for the evaporator of the HP system ( $\dot{\mathrm{Q}}_{\mathrm{evap}}$ ) using the following equations:

$$
\begin{aligned}
& \dot{\mathrm{Q}}_{\text {evap }}=\dot{\mathrm{m}}_{\text {ref }}\left(h_{\text {ref.evap.out }}-h_{\text {ref.evap.in }}\right) \\
& \dot{\mathrm{Q}}_{\text {evap }}=\dot{\mathrm{m}}_{\text {air }}\left(h_{\text {air.evap.in }}-h_{\text {air.evap.out }}\right)
\end{aligned}
$$

The heat transfer rate can be calculated for the condenser of the HP system ( $\left.\dot{Q}_{\text {cond }}\right)$ using the following equations:

$$
\begin{aligned}
& \dot{\mathrm{Q}}_{\text {cond }}=\dot{\mathrm{m}}_{\text {ref }}\left(h_{\text {ref.cond.in }}-h_{\text {ref.cond.out }}\right) \\
& \dot{\mathrm{Q}}_{\text {cond }}=\dot{\mathrm{m}}_{\text {air }}\left(h_{\text {air.cond.out }}-h_{\text {air.cond.in }}\right)
\end{aligned}
$$

or

$$
\begin{array}{r}
\dot{\mathrm{Q}}_{\text {cond }}=\dot{\mathrm{m}}_{\text {air }} \mathrm{C}_{\text {p.air }}\left(\mathrm{T}_{\text {air.cond.out }}-\mathrm{T}_{\text {air.cond.in }}\right) \\
\text { for } \quad \dot{\mathrm{m}}_{\text {air }}=\rho_{\text {air }} \cdot \mathrm{V}_{\text {air }} \cdot \mathrm{A}
\end{array}
$$

The heat transfer rate when using the electric heater $\left(\dot{Q}_{\text {elect }}\right)$ can be calculated with the following equation:

$$
\dot{\mathrm{Q}}_{\text {elect }}=\dot{\mathrm{m}}_{\text {air }}\left(h_{\text {air.elect.out }}-h_{\text {air.elect.in }}\right)
$$

The compressor power $\left(\dot{\mathrm{W}}_{\text {comp }}\right)$ can be calculated using the following equation:

$$
\begin{aligned}
& \dot{\mathrm{W}}_{\text {comp }}=\dot{\mathrm{m}}_{\text {ref }}\left(h_{\text {ref.comp.out }}-h_{\text {ref.comp.in }}\right) \\
& \dot{\mathrm{W}}_{\text {comp }}=\dot{\mathrm{Q}}_{\text {cond }}-\dot{\mathrm{Q}}_{\text {evap }}
\end{aligned}
$$

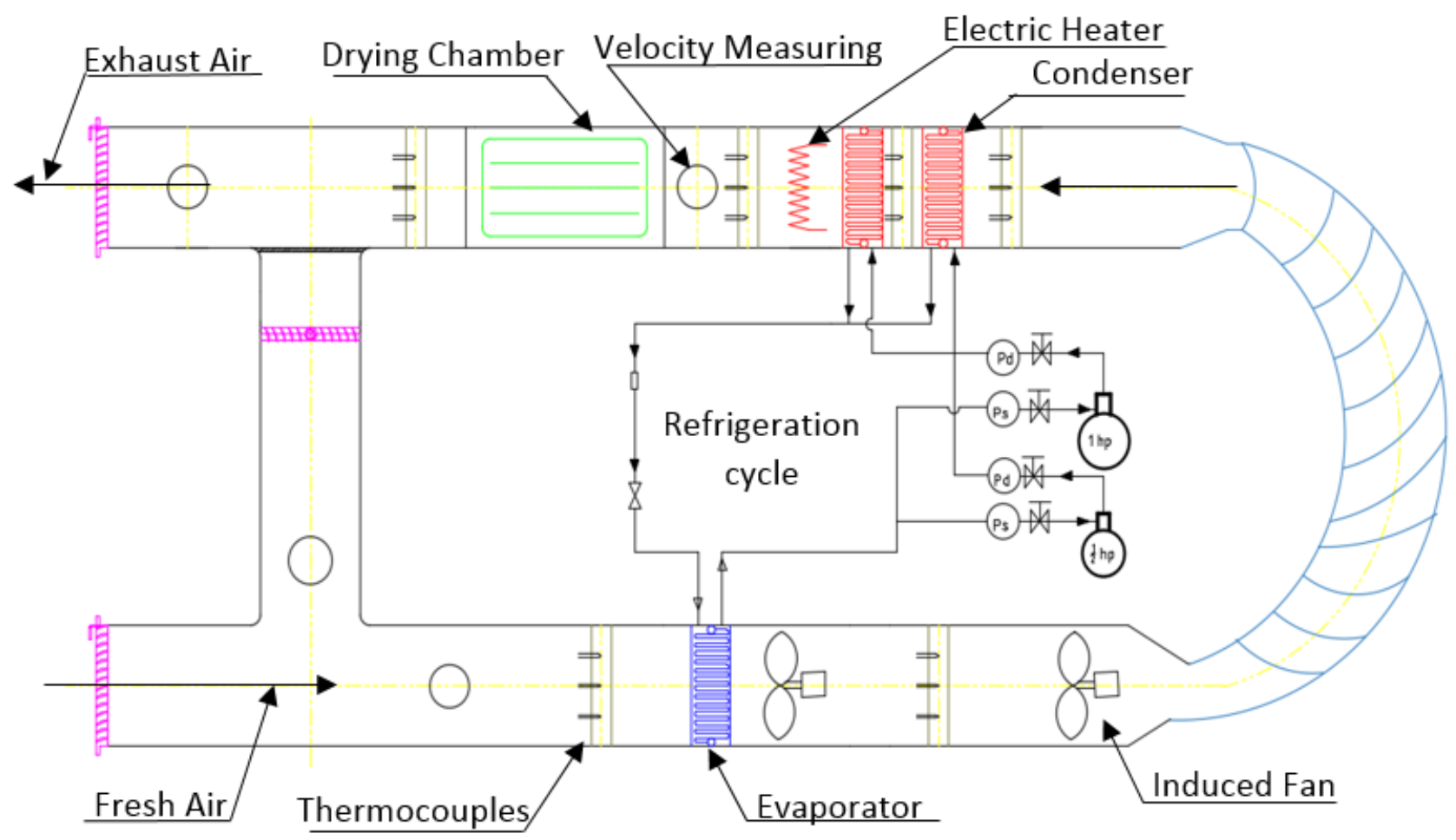

Fig. 1. Schematic of the complete system. 
The power of the electric fan $\left(\dot{\mathrm{W}}_{\mathrm{f}}\right)$ can be calculated using the following equation:

$$
\dot{\mathrm{W}}_{\mathrm{f}}=\dot{\mathrm{m}}_{\mathrm{air}} \Delta \mathrm{P}_{\mathrm{air}}
$$

where $\Delta \mathrm{P}_{\text {air }}$ is the pressure change of air through the electric fan.

The dry basis moisture content $\left(\mathrm{MC}_{\mathrm{db}}\right)$ of the sample can be calculated using the following equation:

$$
\mathrm{MC}_{\mathrm{db}}=\frac{\mathrm{M}_{\mathrm{i}}-\mathrm{M}_{\mathrm{d}}}{\mathrm{M}_{\mathrm{d}}}
$$

The wet basis moisture content $\left(\mathrm{MC}_{\mathrm{wb}}\right)$ of the sample can be calculated using the following equation:

$$
\mathrm{MC}_{\mathrm{wb}}=\frac{\mathrm{M}_{\mathrm{i}}-\mathrm{M}_{\mathrm{d}}}{\mathrm{M}_{\mathrm{i}}}
$$

The moisture ratio (MR) found during the drying experiments was calculated using the following equation:

$$
\mathrm{MR}=\frac{\mathrm{MC}-\mathrm{MC}}{\mathrm{M} C_{\mathrm{o}}-\mathrm{M} C_{\mathrm{e}}}
$$

However, due to the high moisture content of the fresh product, Eq. (12) can be written as follows.

$$
\mathrm{MR}=\frac{\mathrm{MC}}{\mathrm{M} C_{\mathrm{o}}}
$$

The drying rate (DR) of the over-drying experiments can be estimated using the following equation [22]:

$$
\mathrm{DR}=\frac{\mathrm{dMC}}{\mathrm{dt}}=\frac{\mathrm{MC}_{\mathrm{t}+\mathrm{dt}}-\mathrm{MC}_{\mathrm{t}}}{\mathrm{dt}}
$$

The MER and the efficiency $\left(\eta_{d r y}\right)$ of the drying process can be estimated using the following equations:

$$
\operatorname{MER}_{\text {dry }}=\dot{\mathrm{m}}_{\text {air }}\left(\omega_{\text {air.out }}-\omega_{\text {air.in }}\right)
$$

$$
\eta_{d r y}=\frac{\omega_{\text {dry.out }}-\omega_{\text {dry.in }}}{\omega_{\text {dry.out.sat }}-\omega_{\text {dry.in }}}
$$

The $\left(\mathrm{COP}_{\mathrm{R}}\right)$ and $\left(\mathrm{COP}_{\mathrm{hp}}\right)$ of the vapor compression cycle and the system as a whole $\left(\mathrm{COP}_{\mathrm{ws}}\right)$ during the drying process can be represented as follows:

$$
\begin{aligned}
& \mathrm{COP}_{\mathrm{R}}=\frac{\dot{\mathrm{Q}}_{\text {evap }}}{\dot{\mathrm{W}}_{\text {comp }}} \\
& \mathrm{COP}_{\mathrm{HP}}=\frac{\dot{\mathrm{Q}}_{\text {cond }}}{\dot{\mathrm{W}}_{\text {comp }}} \\
& \mathrm{COP}_{\mathrm{ws}}=\frac{\dot{\mathrm{Q}}_{\text {cond }}}{\dot{\mathrm{W}}_{\text {comp }}+\dot{\mathrm{Q}}_{\text {elect }}+\dot{\mathrm{W}}_{\mathrm{f}}}
\end{aligned}
$$

The SMER of the system and SEC are shown in the following equation:

$$
\begin{aligned}
& \text { SMER }=\frac{\text { MER }}{\dot{\mathrm{W}}_{\text {comp }}+\dot{\mathrm{Q}}_{\text {elect }}+\dot{\mathrm{W}}_{\mathrm{f}}} \\
& \mathrm{SEC}=\frac{\dot{\mathrm{W}}_{\text {comp }}+\dot{\mathrm{Q}}_{\text {elect }}+\dot{\mathrm{W}}_{\mathrm{f}}}{\mathrm{MER}}
\end{aligned}
$$

In the following section the experimental set-up of the HPD will be explained to study the performance of the drying system.

\section{EXPERIMENTAL SETUP AND PROCEDURE}

\subsection{Description of experimental setup}

The experimental setup was developed to study the performance of the HPD and EHD under different conditions. The setup image is given in Figure 2. The setup largely consists of a refrigeration cycle and an air cycle.

\subsubsection{Vapor compression cycle}

The refrigeration cycle operates by means of a vapor compression cycle, involving a compressor, evaporator, condenser, and capillary tube. 
Experimental devices in other works have included two compressors to study the effects of multi-stage pressure, but in this, only one compressor was used. The hermetic reciprocating compressor used for the device is AJE4492AGZ, which has the following specifications: code: CAJ4492A, high backpressure compressor with $1 \mathrm{hP}$ power, cooling effect of $1100 \mathrm{~W}$, voltage of 187-242 $\mathrm{V}$, frequency of $50 \mathrm{~Hz}$, working on an R-12 refrigerant. The evaporator is a heat exchanger, in which the freon absorbs heat from its surroundings for evaporation from the mixture stage to the vapor phase at the expense of cooling the surroundings. The type of evaporator used is a radiator coil that has the following specifications: CW 1-3 model, with a fin and tube heat exchanger, tube of copper 0.40 , fins of aluminum $0.12,3$ rows, and 9 tubes. A condenser is a device or unit used to condense freon from a vapor state to a liquid at the expense of heating the surroundings. The experimental device includes two condensers for high-load applications, but in this work, only the first was used. The specifications of the used condenser in the HPD are as follows: CW 1-3 model, air-cooled condenser, tube of copper 0.40 , fins of aluminum $0.12,3$ rows, 9 tubes, heat load $1865 \mathrm{~W}$, and outer dimensions of 25 $\times 25 \times 10 \mathrm{~cm}$ in length, height, and width respectively. The capillary tube is of copper, with a very small inner diameter. The inner diameter of the capillary tube used is $0.5 \mathrm{~mm}$.

\subsubsection{Drying air cycle}

The air cycle occurs in air in the air duct. this channel is made of a sheet whose dimensions are $28 \times 28 \mathrm{~cm}$, height and width, respectively, and a sheet thickness of $0.7 \mathrm{~mm}$. The air cycle contains air supply devices (air fans), an electric heater, and a drying chamber.

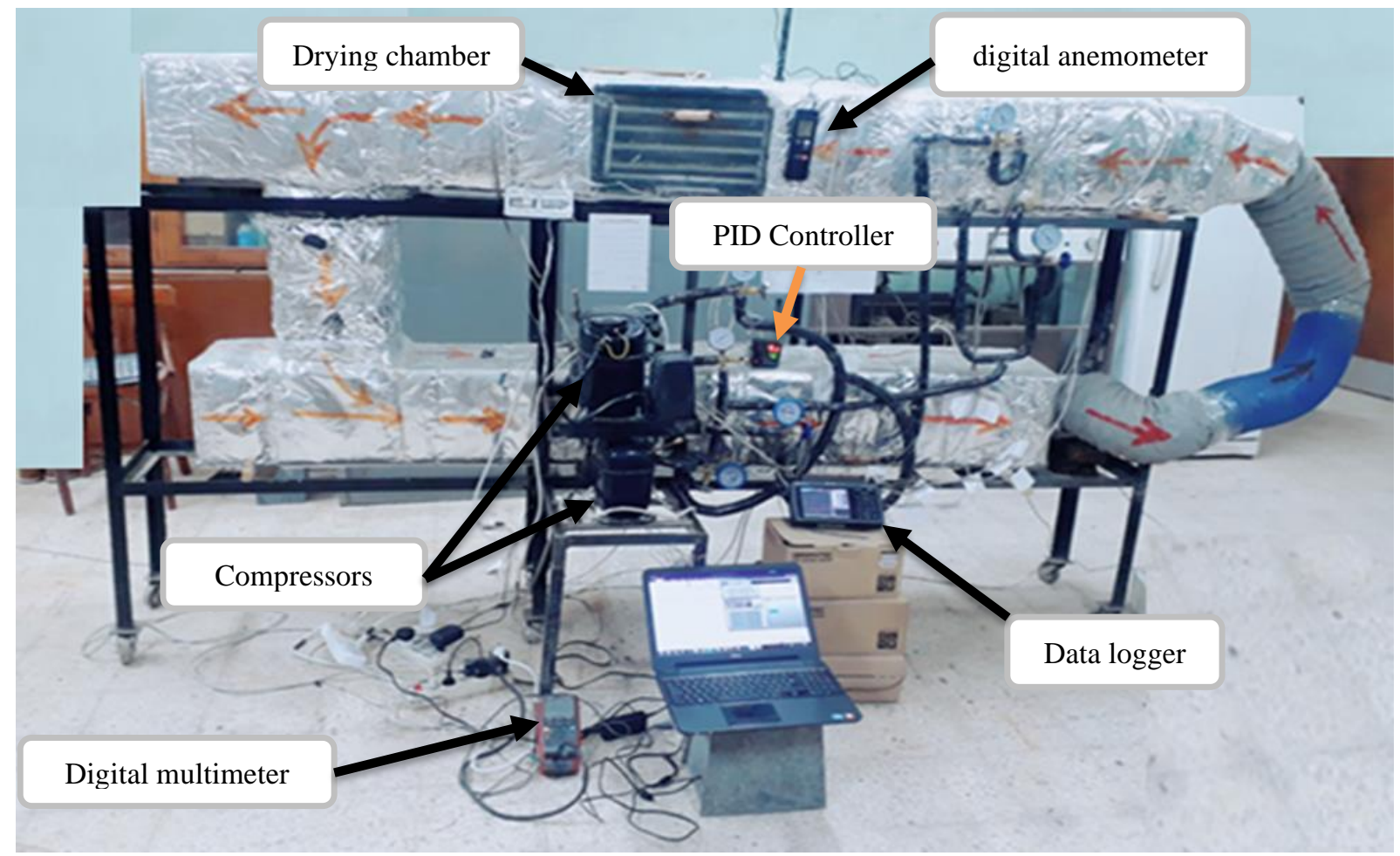


Fig. 2. Photo of the device setup.

The experimental device shown in Figures 1 and 2 has a bypass that is used in other contexts but not in this experiment, in which it was kept closed (no recirculation). Fans were used to supply the air, and the experimental device included two fans that ran at different speeds. The specifications of the air fans used are as follows: Model: 2-0220010 induced axial fan at $60 \mathrm{~W}$ and $1300 \mathrm{rpm}$ and at $90 \mathrm{~W}$ and $1300 \mathrm{rpm}$. The electric heater used had a capacity of $2.4 \mathrm{~kW}$ and was used as an auxiliary device in an HPD operation similar to that of Fatouh et al. [11]. The drying chamber is in the duct, lying after the condenser and the electric heater. It has dimensions of 40,20 , and $20 \mathrm{~cm}$ for length, width, and height respectively. It consists of 4 shelves to distribute the product to be dried homogeneously.

\subsection{Principles of operation of the HPD}

As mentioned, the system performs a vapor compression cycle and an air cycle. When the compressor is running, the refrigerant mass flow passes through the components of the cycle as the evaporator converts the refrigerant from a liquid phase to a gaseous or vapor phase, and the condenser condenses the vapor to a liquid. Air passes through the evaporator to be dried and then passes through the condenser to be heated. The dry, hot air enters the drying chamber to remove moisture from the materials to be dried. The drying air temperatures were controlled by the PID controller with an accuracy of $\pm 1^{\circ} \mathrm{C}$.

Onions are the material to be dried. Selected onion samples were cleaned, peeled by hand, and trimmed. Then, they were cut into slices $3 \mathrm{~mm}$ thick and 15 to $20 \mathrm{~mm}$ long.

In all, $500 \mathrm{~g}$ Egyptian onion slices were distributed uniformly at $6.25 \mathrm{~kg} / \mathrm{m}^{2}$ loading in a thin layer over the four drying trays, and uniform air distribution in the chamber was ensured. The different drying air temperatures and the drying air velocity were controlled in experiments. The samples were weighed at regular intervals of $10 \mathrm{~min}$ until the goal weight of the samples (115 g) (26\% final moisture content) was reached. For the dry base, onion slices were dried from 4.88 $g_{\text {water }} / g m_{d m}$ moisture content to 0.35 $g m_{\text {water }} / g m_{d m}$ moisture in the initial stage of multi-stage drying.

\subsection{Instrumentation and measurements}

The dry and wet-bulb temperatures were measured using a K-Type thermocouple with a measurement range of $-50^{\circ} \mathrm{C}$ to $200^{\circ} \mathrm{C}$, and the uncertainty was $\pm 0.1^{\circ} \mathrm{C}$. Air velocity was measured using a digital anemometer (Testo 425) with a measurement range from 0 to 20 $\mathrm{m} / \mathrm{s}$ and an uncertainty of $\pm 0.01 \mathrm{~m} / \mathrm{s}$. The onions were weighed on a digital scale (SF400) with a measurement range from 0 to $10,000 \mathrm{~g}$, and the uncertainty was $\pm 1 \mathrm{~g}$. The power consumed was measured with a digital multimeter (UT71E), with a measurement range from 0 to $2500 \mathrm{~W}$ and an uncertainty of $\pm 2.0 \%$. When the device is turned on, the fan runs continuously. During the use of the EHD, the electric heater turns on and off in response to the use of a PID controller. While the HPD was in use, the compressor was running continuously. The electric heater, as an auxiliary device, turned on and off to bring about the required temperature.

\subsection{Experimental procedure}


The experiments were performed using the following setting procedure:

1. The measuring instruments were installed and prepared to work.

2. Onion samples were sliced, weighed, and then homogeneously distributed over the surfaces of the drying chamber.

3. The drying chamber was placed above the digital scale in the path of the hot air through the duct past the condenser and the electric heater.

4. The drying chamber gate was closed tightly to ensure there would be no air leakage.

5. The data logger, the electric power meter, and the fan were turned on for the required velocity, and then the electric heater and the compressor of the HP were activated.

6. The weight of the onion slices was read every $10 \mathrm{~min}$ and was noted on the spreadsheet.

7. The instruments and the machine were turned off after the final weight of the onion slices was assessed.

\section{RESULTS AND DISCUSSION}

The characteristics that affected dryer performance and influenced the choice of drying system were drying time, energy consumed, moisture content, DR, and experimental drying equations. On the dry basis, the amount of the initial moisture content of the onion slices was 4.88 $\mathrm{gm}_{\text {water }} / \mathrm{gm}_{\mathrm{dm}}$, and the drying was performed to a final moisture amount of dry matter of $0.35 \mathrm{gm}_{\text {water }} / \mathrm{gm}_{\mathrm{dm}}$. Experiments were performed in the air source HPD and EHD while drying the air at $0.2,0.3$, and $0.4 \mathrm{~m} / \mathrm{s}$ and drying air temperature $50^{\circ} \mathrm{C}, 60^{\circ} \mathrm{C}$, and $70^{\circ} \mathrm{C}$.

The air conditions were sampled before and after each component and plotted in a psychometric chart, as shown in Figure 3.

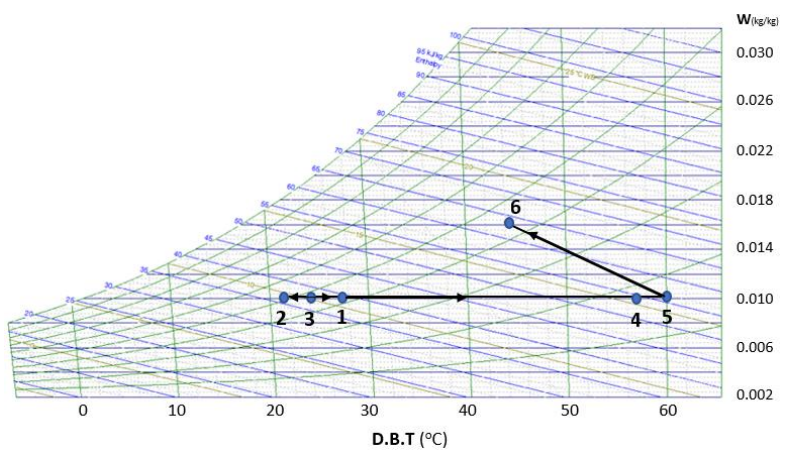

Fig. 3. Psychometric chart of a sample process air.

1- evaporator-in, 2- evaporator-out, 3- condenser-in, 4condenser-out or electric heater-in, 5- electric heaterout or dryer-in, 6- dryer-out.

\subsection{Drying time}

A total of nine experiments were performed with the electric heater, and nine more experiments were done by drying with a $\mathrm{HP}$ at drying temperatures of $50^{\circ} \mathrm{C}, 60^{\circ} \mathrm{C}$, and $70^{\circ} \mathrm{C}$. The air velocities were $0.2,0.3$, and 0.4 $\mathrm{m} / \mathrm{s}$. Figure 4 shows the difference in moisture content of onion slices using electric heater drying and HPD as a function of drying time at $0.2 \mathrm{~m} / \mathrm{s}$. Figure 4 shows that as the drying temperature increases, the drying time decreases. Figures 5 and 6 show the variation in moisture content of the onion slices using electric heater drying and HPD as a function of drying time at 0.3 and $0.4 \mathrm{~m} / \mathrm{s}$, showing that as drying velocity increased, drying time decreased.

Figures 4-6 show the relationship between drying time and drying temperature and velocity. Increasing the temperature or velocity of the drying air increases the heat and mass transfer between the drying air and the materials to be dried. Changes in the velocity of the air flow played an important role in transferring the evaporated water from the surface of the product and reducing drying time. Thus, the minimum drying time is at the highest speed, which is $0.4 \mathrm{~m} / \mathrm{s}$, and the 
highest temperature was $70^{\circ} \mathrm{C}$. The drying, which indicates that the drying time by HPD, was less than that when using EHD at the same temperature and velocity.

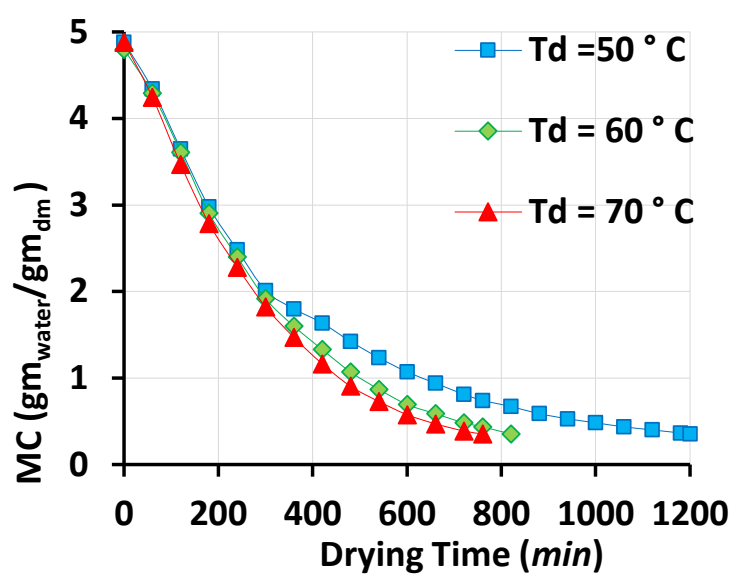

(a)
Time when using EHD was $570 \mathrm{~min}$, and when using HPD it was 510 min, as shown in Figure 7.

Fig. 4. Moisture content variation as a function of drying time at a drying speed of $0.2 \mathrm{~m} / \mathrm{s}$ and a different drying temperature: (a) electric heater drying and (b) heat pump drying.

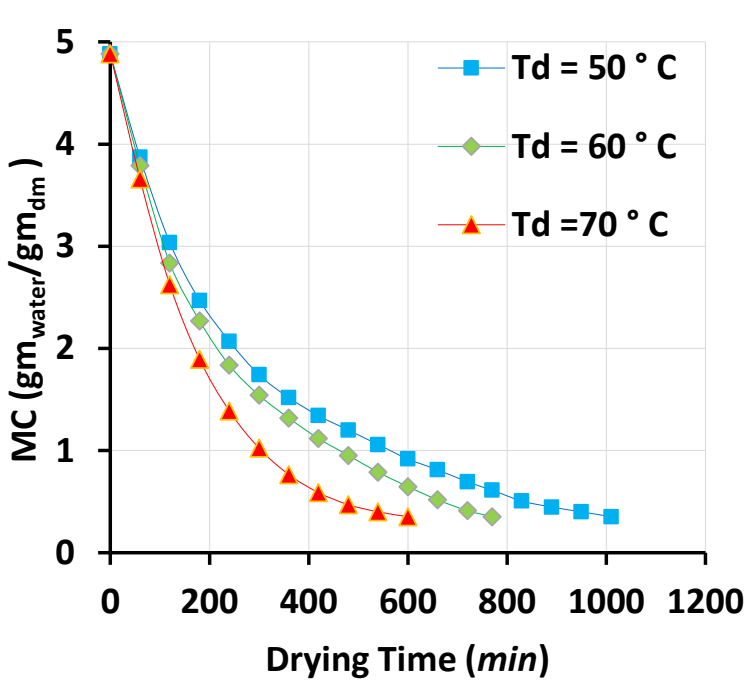

(a)

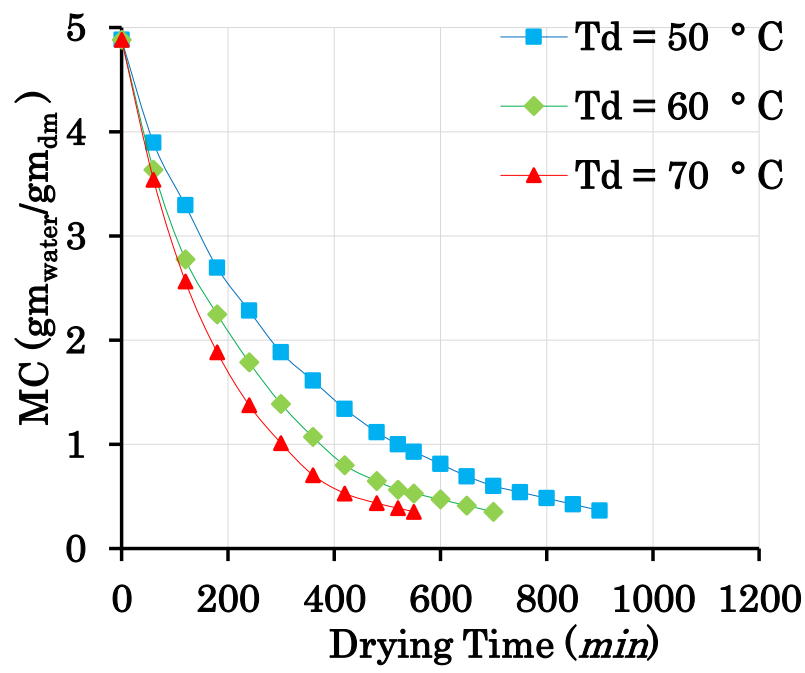

(b)

Fig. 5. Moisture content variation as a function of drying time at a drying speed of $0.3 \mathrm{~m} / \mathrm{s}$ and different drying temperature: (a) electric heater drying and (b) heat pump drying. 
Vol. 41, No.2. July 2022

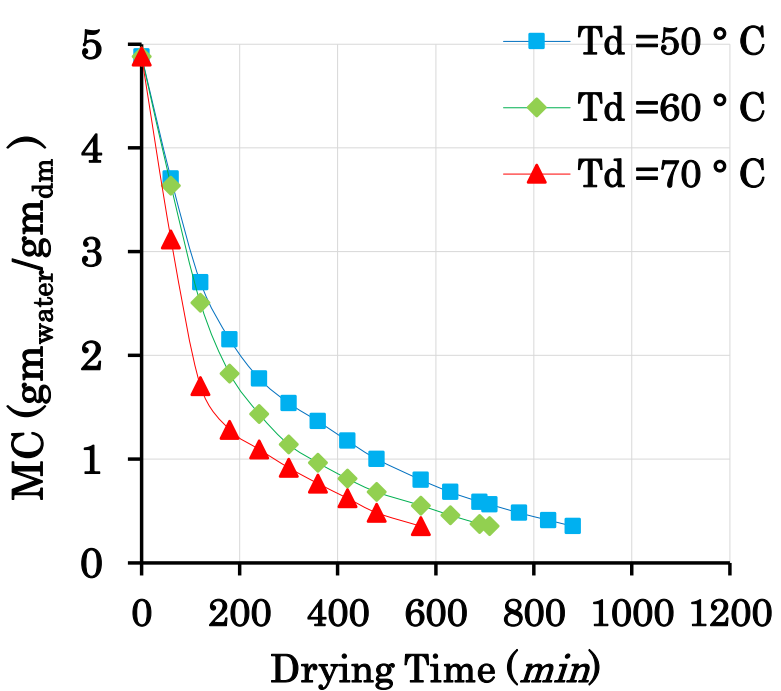

(a)

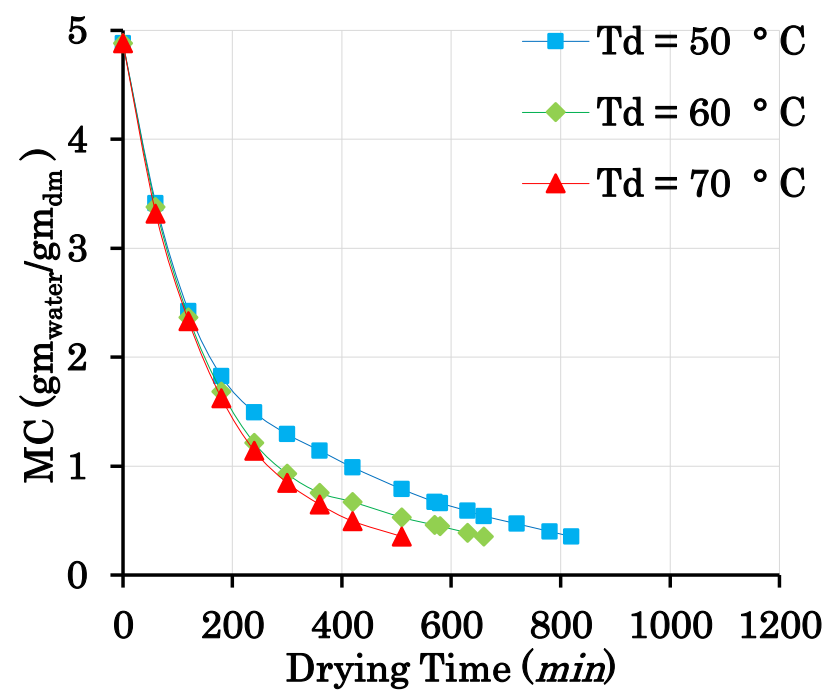

(b)

Fig. 6. Moisture content variation as a function of drying time at a drying speed of $0.4 \mathrm{~m} / \mathrm{s}$ and different drying temperature: (a) electric heater drying and (b) heat pump drying.

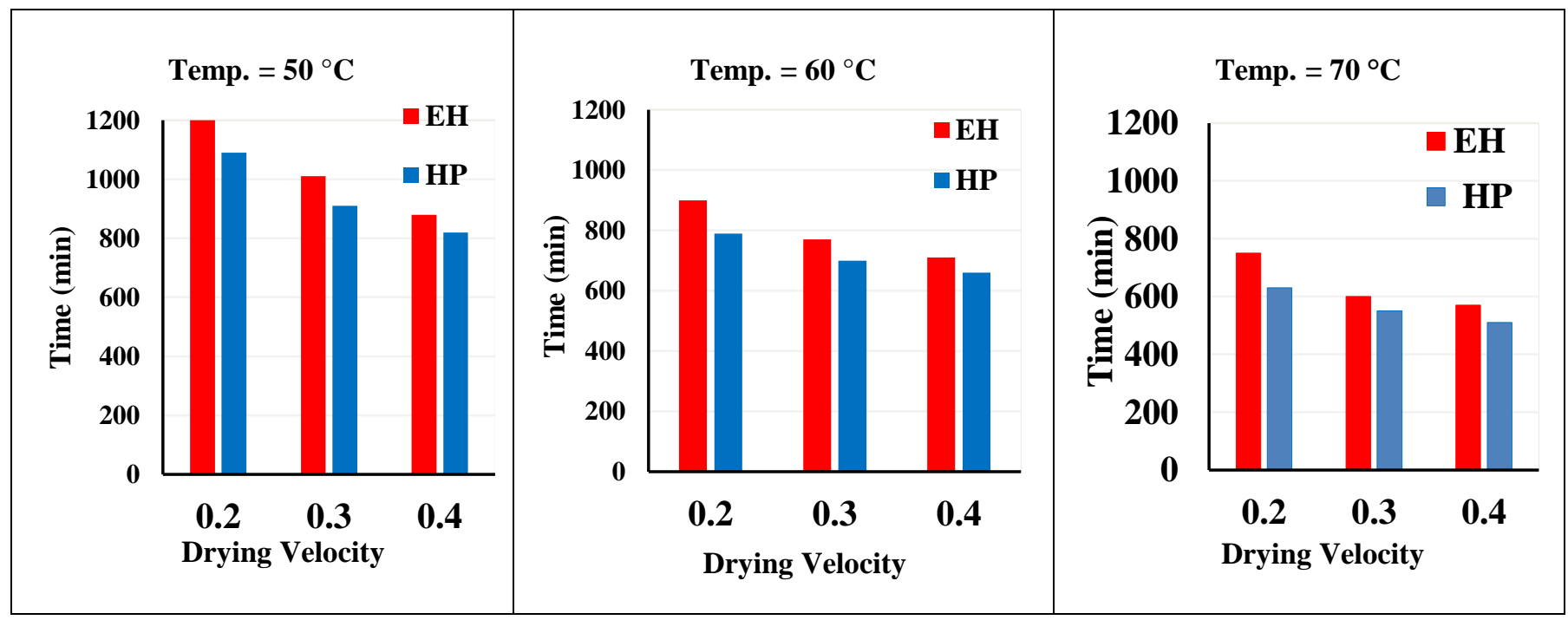

Fig. 7. The time difference between an EHD and an HPD at different drying temperatures and velocities.

\subsection{Power consumed}

Energy consumption measured with a smart digital scale. Using Simpson's 3/8 rule, the total energy consumed was calculated, and it was found that drying using an electric heater consumed the least energy at $\mathrm{V}_{\mathrm{d}}=0.4$ $\mathrm{m} / \mathrm{s}$ and $\mathrm{T}_{\mathrm{d}}=50^{\circ} \mathrm{C}$, and drying with a $\mathrm{HP}$ consumed the least energy at $\mathrm{V}_{\mathrm{d}}=0.2 \mathrm{~m} / \mathrm{s}$ and $\mathrm{T}_{\mathrm{d}}=50^{\circ} \mathrm{C}$. Figure (8) shows an SEC comparison between EHD and HPD. The COP of using vapor compression cycle according to refrigerant effect was 1.5 and according to heat pump was 2.5 . 
Vol. 41, No.2. July 2022

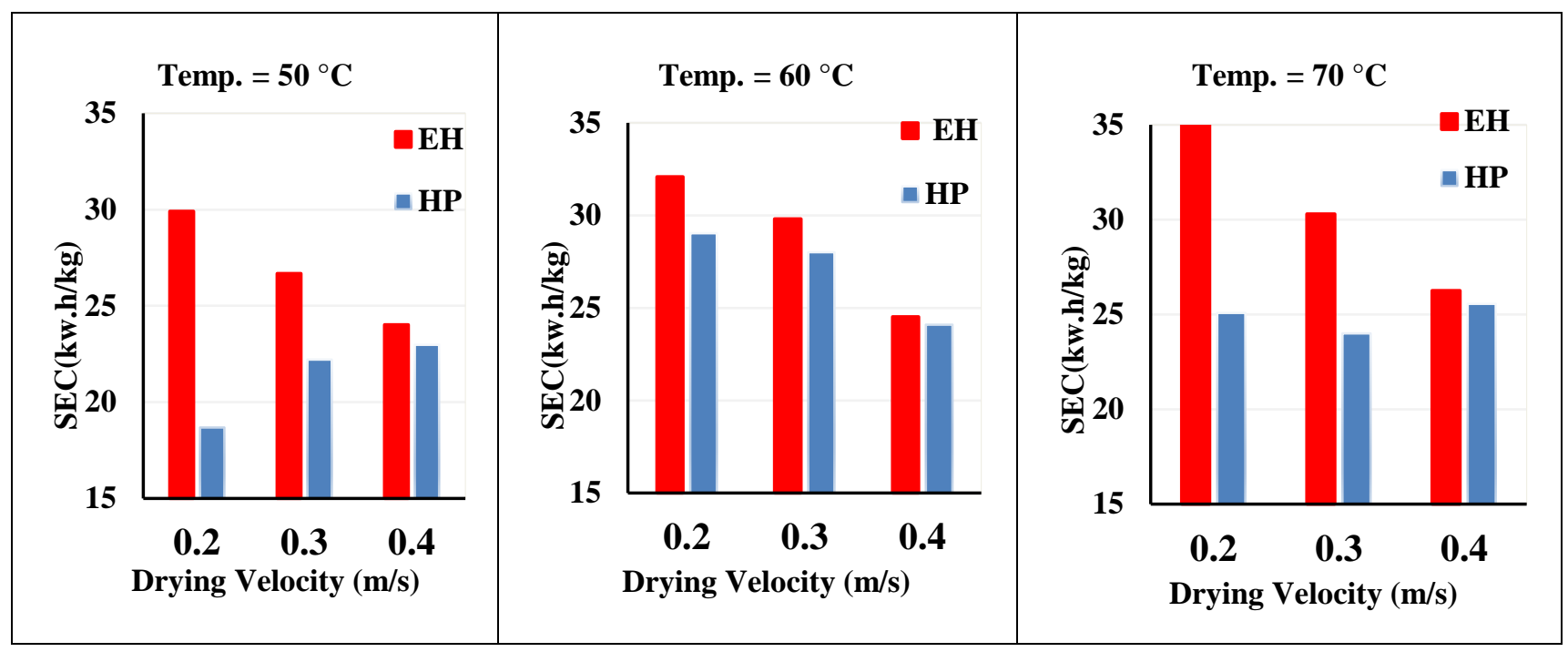

Fig. 8. The difference in SEC for EHD and HPD at different drying temperatures and velocities.

The results showed that using HPD saves more energy than using the EHD at the same drying temperature and velocity. The main reason for this is that the COP for the HP cycle is more than the unit. A comparison between the SEC values in our study and that of previous work [18], [23], and [24] was performed, as shown in Figure (9). The SEC value was enhanced by $69.5 \%$ compared to [23] and approximately similar to the values in 24].

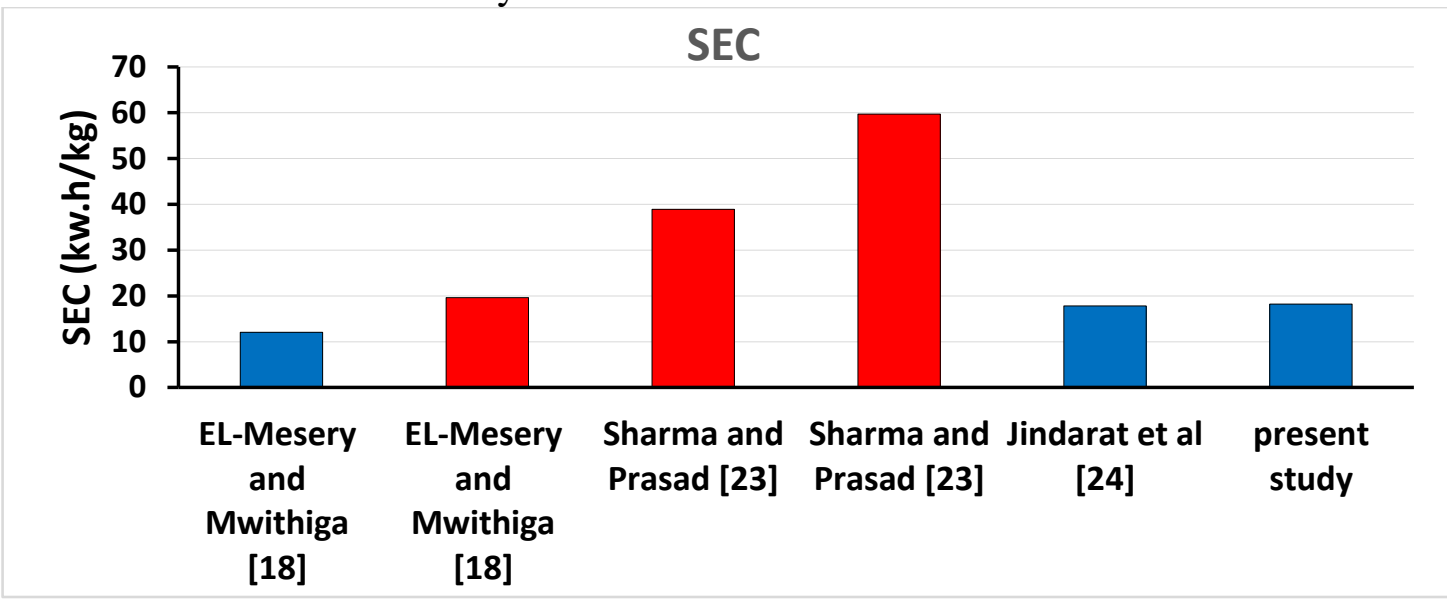

Fig. 9. Comparison of SEC values with those of other works

\subsection{Moisture ratio}

The MR is the ratio of the instantaneous to the initial MC of a material. Figure 10 shows the variation in MR versus drying time at $50^{\circ} \mathrm{C}$ as the drying temperature for the best condition for drying the electric heater and the HPD. Figure 10 shows that using HPD is better than using electric heater drying, taking less time and requiring less energy consumption. The MR curve obtained is similar to that found in previous works on drying as $[22,25]$.

\subsection{Drying rate}


The DR is the change in the moisture content of a material per unit time. Figure 11 shows the variation of DR versus drying time of EHD and HPD at 0.2 and $0.4 \mathrm{~m} / \mathrm{s}$ as drying velocity and at a drying temperature of $50^{\circ} \mathrm{C}$. This shows that the DR is high in the beginning but then decreases with the passage of time because the moisture content at the beginning is large, making it evaporate easily and leave the surface of the material (high heat and mass transfer), while ultimately the opposite happens. This also shows that the DR curve is similar to that shown in earlier work on drying.

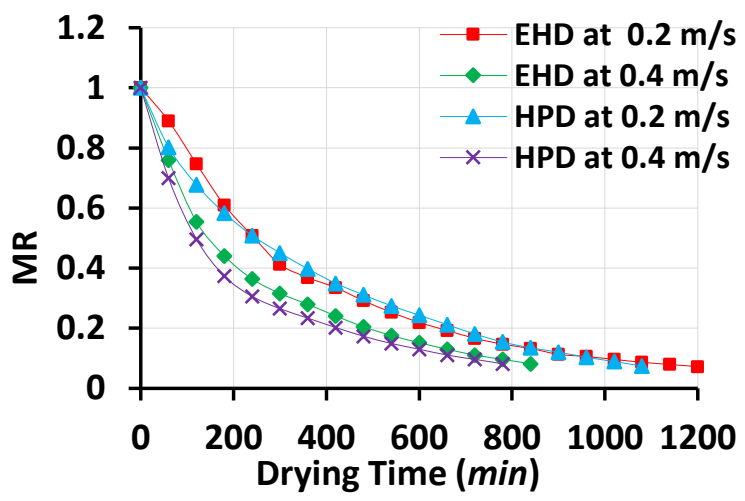

Fig. 10. Variation of moisture ratio as a function of drying time at $50^{\circ} \mathrm{C}$ drying temperature.

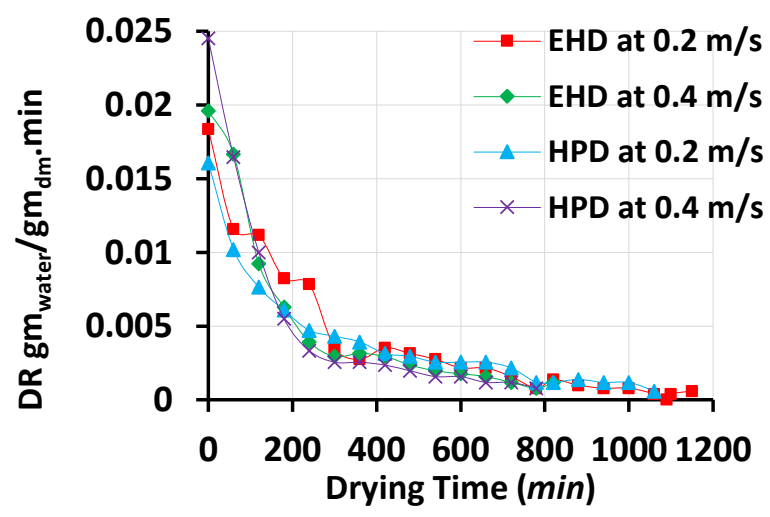

Fig. 11. Variation in the drying rate as a function of drying time.

\subsection{Empirical drying equations}

Usually, the drying models adopted in the analysis of drying properties are theoretical, semi-theoretical, or purely experimental [26]. The empirical equations for MR for the five common experimental models are presented in Table 2. Mazza and Lemaguer [27] derived theoretical models for drying any material by convection, where $\mathrm{k}$ is the drying constant $(\mathrm{s}-1)$ and $\mathrm{t}$ is the drying time (min).

Figure 12 shows three models from among the common five drying models for EHD and HPD under conditions that achieved the lowest energy consumption. The drying constants $\mathrm{k}, a$, and $\mathrm{n}$ for drying Egyptian onion slices by EHD and HPD for the five drying models are presented in Table 3 . The $\mathrm{R}^{2}$ parameter and the SEE were determined for the drying models used, namely, Newton, Page, Modified Page, Henderson and Pabis, Wang, and Singh.

Table 2. Mathematical models for drying

\begin{tabular}{|c|c|c|c|}
\hline No. & Name & Model equation & Refs. \\
\hline 1 & Newton & $M R=\exp (-k t)$ & $\begin{array}{l}{[28],} \\
{[29]}\end{array}$ \\
\hline 2 & Page & $\begin{array}{l}M R \\
=\exp \left(-k t^{n}\right)\end{array}$ & {$[25]$} \\
\hline 3 & Modified Page & $\begin{array}{l}M R \\
=\exp \left[-(k t)^{n}\right]\end{array}$ & [15] \\
\hline 4 & $\begin{array}{c}\text { Henderson and } \\
\text { Pabis }\end{array}$ & $\begin{array}{l}M R \\
=a \cdot \exp (-k t)\end{array}$ & $\begin{array}{l}{[30],} \\
{[31]}\end{array}$ \\
\hline 5 & $\begin{array}{l}\text { Wang and } \\
\text { Singh }\end{array}$ & $\begin{array}{l}M R \\
=1+a t+b t^{2}\end{array}$ & [32] \\
\hline
\end{tabular}

The best model for drying the Egyptian onion slices with EHD was the Page model, where the maximum value of $\mathrm{R}^{2}$ was 0.9919 , and the lowest value for SEE was 0.0162, 
approved with [15, 33]. However, for drying with HPD, the best model was inferred to be the Henderson and Pabis, where the maximum value for $\mathrm{R}^{2}$ was 0.9982 and the lowest value of SEE was 0.0275, approved using [26].

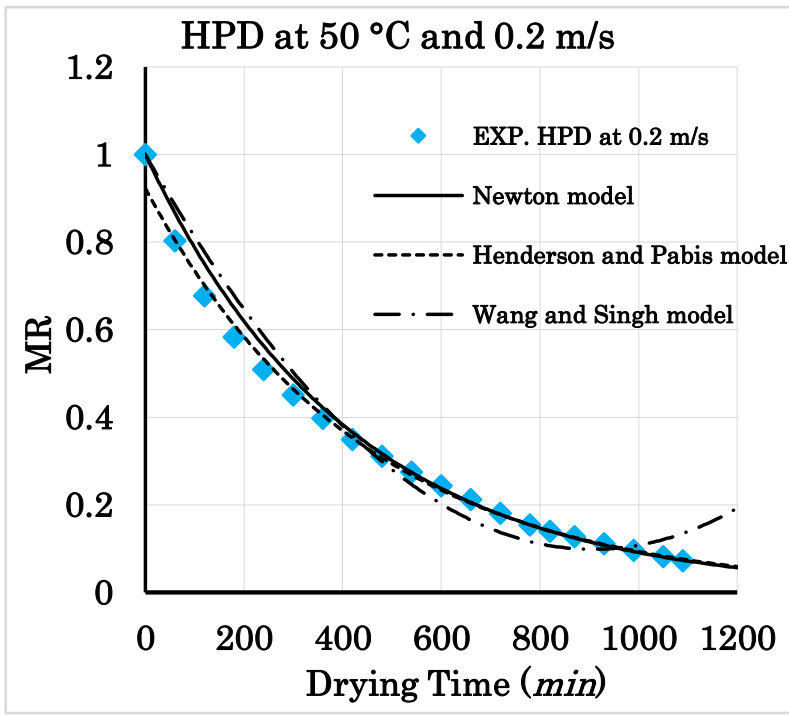

(b)

Fig. 12. Empirical models of onion slices drying by (a) EHD and (b) HPD.

Table 3. Drying constants, coefficients of the models $\left(\mathrm{R}^{2}\right)$, and standard error of estimate (SEE)

\begin{tabular}{|c|c|c|c|c|c|c|c|}
\hline \multirow[t]{2}{*}{ Model } & \multirow[t]{2}{*}{ Model equation } & \multicolumn{3}{|c|}{ EHD } & \multicolumn{3}{|c|}{ HPD } \\
\hline & & $\begin{array}{l}\text { Equation } \\
\text { constants }\end{array}$ & $\mathbf{R}^{2}$ & SEE & $\begin{array}{l}\text { Equation } \\
\text { constants }\end{array}$ & $\mathbf{R} 2$ & SEE \\
\hline Newton & $M R=\exp (-k t)$ & $\mathrm{K}=0.003$ & 0.9653 & 0.0460 & $\mathrm{~K}=0.002$ & 0.9953 & 0.0275 \\
\hline page & $M R=\exp \left(-k t^{n}\right)$ & $\begin{array}{l}\mathrm{K}=0.0126 \\
\mathrm{n}=0.7857\end{array}$ & 0.9919 & 0.0162 & $\begin{array}{l}\mathrm{K}=0.0063 \\
\mathrm{n}=0.8539\end{array}$ & 0.9962 & 0.0303 \\
\hline $\begin{array}{l}\text { Modified } \\
\text { Page }\end{array}$ & $\begin{array}{l}M R \\
=\exp \left[-(k t)^{n}\right]\end{array}$ & $\begin{array}{l}\mathrm{K}=0.0038 \\
\mathrm{n}=0.7857\end{array}$ & 0.9919 & 0.169 & $\begin{array}{l}\mathrm{K}=0.0026 \\
\mathrm{n}=0.8539\end{array}$ & 0.9962 & 0.1484 \\
\hline $\begin{array}{l}\text { Henderson } \\
\text { and Pabis }\end{array}$ & $\begin{array}{l}M R \\
=a \cdot \exp (-k t)\end{array}$ & $\begin{array}{l}\mathrm{K}=0.003 \\
a=0.8024\end{array}$ & 0.9881 & 0.0460 & $\begin{array}{l}\mathrm{K}=0.002 \\
a=0.923\end{array}$ & 0.9982 & 0.0275 \\
\hline $\begin{array}{l}\text { Wang and } \\
\text { Singh }\end{array}$ & $\begin{array}{l}M R \\
=1+a t+b t^{2}\end{array}$ & $\begin{array}{l}a=-0.0028 \\
b=2 \times 10^{-6}\end{array}$ & 0.9236 & 0.0571 & $\begin{array}{l}a=-0.0020 \\
b=1 \times 10^{-6}\end{array}$ & 0.9606 & 0.0360 \\
\hline
\end{tabular}

Figure 13 shows photos of fresh and dried onion slices. The dried onion slices showed no change in color or taste after drying. Temperatures above $70^{\circ} \mathrm{C}$ can damage onion slices.

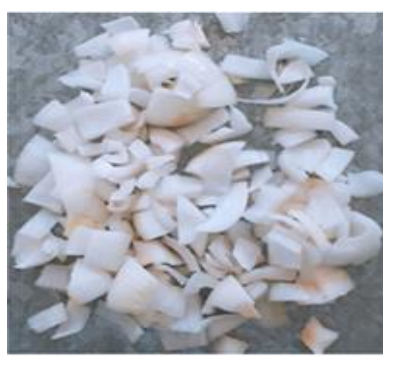

(a)

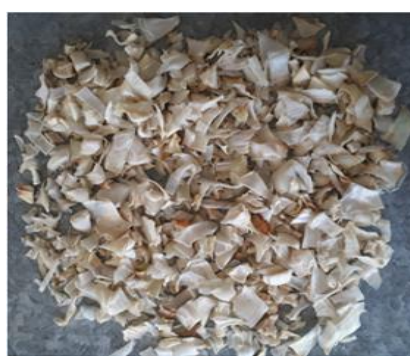

(b) 
Fig. 13. Onion slices (a) before drying and (b) after drying.

\section{CONCLUSIONS}

A comparison of drying onion slices with an electric heater dryer and an HP dryer at different air temperatures and velocities was conducted to establish how the quality of dried products can be preserved. In this study, we designed and implemented a laboratory EHD and HPD, with the following results:

- Using an HP dryer can effectively increase drying energy efficiency.

- Saving the highest energy or lowest energy consumption was obtained with an HPD at an air velocity of $0.2 \mathrm{~m} / \mathrm{s}$ and $50^{\circ} \mathrm{C}$.

- Experiments showed that energy saving with HPD compared to EHD was $22.2 \%$. The improvement can be increased from this value if a refrigerant cycle is used with a high COP and the air humidity removed through the evaporator.

- Drying constants of the different models were obtained, and the best $\mathrm{R}^{2}$ value for Egyptian onion slices to give a change in drying ratio according to drying time was established.

References

[1] J. Mitra, S. á. Shrivastava, and P. Rao, "Onion dehydration: a review," Journal of food science and technology, vol. 49, pp. 267-277, 2012.

[2] L. Sun, M. R. Islam, J. Ho, and A. Mujumdar, "A diffusion model for drying of a heat sensitive solid under multiple heat input modes," Bioresource Technology, vol. 96, pp. 1551-1560, 2005.

M. Zielinska, P. Zapotoczny, O. Alves-Filho, T. Eikevik, and W. Blaszczak, "A multi-stage combined heat pump and microwave vacuum drying of green peas," Journal of Food Engineering, vol. 115, pp. 347-356, 2013.

[4] M. Aktaş, L. Taşeri, S. Şevik, M. Gülcü, G. Uysal Seçkin, and E. C. Dolgun, "Heat pump drying of grape pomace: Performance and product quality analysis," Drying Technology, vol. 37, pp. 1766-1779, 2019.

[5] A. S. Mujumdar, Handbook of industrial drying, revised and expanded vol. 2: CRC Press, 1995.

[6] N. Colak and A. Hepbasli, "A review of heat pump drying: Part 1-Systems, models and studies," Energy conversion and management, vol. 50, pp. 2180-2186, 2009.

[7] R. Queiroz, A. L. Gabas, and V. R. N. Telis, "Drying kinetics of tomato by using electric resistance and heat pump dryers," Drying Technology, vol. 22, pp. 1603-1620, 2004.

[8] K. J. Chua, S. K. Chou, and W. Yang, "Advances in heat pump systems: A review," Applied energy, vol. 87, pp. 3611-3624, 2010.

[9] N. Colak and A. Hepbasli, "A review of heat-pump drying (HPD): Part 2Applications and performance assessments," Energy Conversion and Management, vol. 50, pp. 2187-2199, 2009.

[10] P. Sarsavadia, R. Sawhney, D. Pangavhane, and S. Singh, "Drying behaviour of brined onion slices," Journal of Food Engineering, vol. 40, pp. 219-226, 1999.

[11] M. Fatouh, M. Metwally, A. Helali, and M. Shedid, "Herbs drying using a heat pump dryer," Energy Conversion 
and Management, vol. 47, pp. 26292643, 2006.

[12] N. H. A. Tajudin, S. M. Tasirin, W. L. Ang, M. I. Rosli, and L. C. Lim, "Comparison of drying kinetics and product quality from convective heat pump and solar drying of Roselle calyx," Food and Bioproducts Processing, vol. 118, pp. 40-49, 2019.

[13] S. BUDŽAKI, J. LEKO, K. JOVANOVIĆ, J. VISZMEG, and I. KOŠKI, "Air source heat pump assisted drying for food applications: A mini review," Croatian journal of food science and technology, vol. 11, pp. 122-130, 2019.

[14] J. Shen, T. Guo, Y. Tian, and Z. Xing, "Design and experimental study of an air source heat pump for drying with dual modes of single stage and cascade cycle," Applied Thermal Engineering, vol. 129, pp. 280-289, 2018.

[15] İ. Ceylan, M. Aktaş, and H. Doğan, "Mathematical modeling of drying characteristics of tropical fruits," Applied Thermal Engineering, vol. 27, pp. 1931-1936, 2007.

[16] D. Arslan and M. M. Özcan, "Study the effect of sun, oven and microwave drying on quality of onion slices," LWT-Food Science and Technology, vol. 43, pp. 1121-1127, 2010.

[17] C. Mota, C. Luciano, A. Dias, M. J. Barroca, and R. Guiné, "Convective drying of onion: Kinetics and nutritional evaluation," Food and bioproducts processing, vol. 88, pp. 115-123, 2010.

[18] H. S. EL-Mesery and G. Mwithiga, "Comparison of a gas fired hot-air dryer with an electrically heated hotair dryer in terms of drying process, energy consumption and quality of dried onion slices," African journal of agricultural research, vol. 7, pp. 4440-4452, 2012.
[19]

A. Singh, J. Sarkar, and R. R. Sahoo, "Experimentation on solar-assisted heat pump dryer: Thermodynamic, economic and exergoeconomic assessments," Solar Energy, vol. 208, pp. 150-159, 2020.

[20] S. B. Sasongko, H. Hadiyanto, M. Djaeni, A. M. Perdanianti, and F. D. Utari, "Effects of drying temperature and relative humidity on the quality of dried onion slice," Heliyon, vol. 6, p. e04338, 2020.

[21] A. Bahnasawy, Z. El-Haddad, M. ElAnsary, and H. Sorour, "Physical and mechanical properties of some Egyptian onion cultivars," Journal of Food Engineering, vol. 62, pp. 255261, 2004.

[22] M. Aktaş, A. Khanlari, B. Aktekeli, and A. Amini, "Analysis of a new drying chamber for heat pump mint leaves dryer," International Journal of Hydrogen Energy, vol. 42, pp. 1803418044, 2017.

[23] G. Sharma and S. Prasad, "Specific energy consumption in microwave drying of garlic cloves," Energy, vol. 31, pp. 1921-1926, 2006.

[24] W. Jindarat, P. Rattanadecho, S. Vongpradubchai, and Y. Pianroj, "Analysis of energy consumption in drying process of non-hygroscopic porous packed bed using a combined multi-feed microwave-convective air and continuous belt system (CMCB)," Drying Technology, vol. 29, pp. 926938, 2011.

[25] I. Saeed, K. Sopian, and Z. Zainol Abidin, "Drying kinetics of Roselle (Hibiscus sabdariffa L.): dried in constant temperature and humidity chamber," Proc. SPS 2006, pp. 143148, 2006.

[26] M. Aktaş, İ. Ceylan, and S. Yilmaz, "Determination of drying characteristics of apples in a heat 
Vol. 41, No.2. July 2022

pump and solar dryer," Desalination, vol. 239, pp. 266-275, 2009.

[27] G. Mazza and M. LeMaguer, "Dehydration of onion: some theoretical and practical considerations," International Journal of Food Science \& Technology, vol. 15, pp. 181-194, 1980.

[28] Q. Liu and F. Bakker-Arkema, "Stochastic modelling of grain drying: Part 2. Model development," Journal of Agricultural Engineering Research, vol. 66, pp. 275-280, 1997.

[29] M. Hummedia and A. Sheikh, "Determination of drying curves of two varieties of peanuts," Agricultural Mechanization in Asia, Africa and Latin America, vol. 20, pp. 47-51, 1989.
[30] R. C. Guarte, "Modelling the drying behaviour of copra and development of a natural convection dryer for production of high quality copra in the Philippines," 1996.

[31] M. S. Chhinnan, "Evaluation of selected mathematical models for describing thin-layer drying of in-shell pecans," Transactions of the ASAE, vol. 27, pp. 610-0615, 1984.

[32] C. Wang and R. Singh, "A Single Layer Drying Equation for Rough Rice ASAE Paper No. 78-3001," St. Josephs, MI: ASAE, 1978.

[33] D. P. Kumar, H. U. Hebbar, and M. Ramesh, "Suitability of thin layer models for infrared-hot air-drying of onion slices," LWT-Food Science and Technology, vol. 39, pp. 700-705, 2006. 
Vol. 41, No.2. July 2022

\section{مقارنة بين التجفيف باستخدام المضخة الحرارية والتجفيف باستخدام السخان الكهربى لشرائح البصل}

الملخص:

تتطلب المنتجات الغذائية والزر اعية التجفيف لتسهيل النقل و التخزين مع الحفاظ على قيمتهـا الغذائيسة. تـم تطوير العديـ مـن تقنيـات التجفيف و استخدامها على مر العصور. يهدف هذا العمل إلى تقديم مقارنة بين مجفف بمضخة حر ارية (HPD) و ومجفف السـخان الكهربي على تجفيف شر ائح البصل المصري واستنتاج معادلة رياضية له لحسـاب معدل تغيرنسبة الرطوبـة مـع الزمن. اعتمدت المقارنة على المعايير التالية: محتوى الرطوبة ، استهلاك الطاقة ، معدل استخلاص الرطوبة ، معدل استخلاص الرطوبة النوعي ، ووقت التجفيف. تم تقطيع البصل إلى شر ائح بسمك 3 مم و بطول 15 إلى 20 مم. تم تجفيف شـر ائح البصـل عند درجـات حرارة تجفيف 50 و 60 و 70 درجة مئوية وسر عات تجفيف تبلغ 0.2 ، 0.3 ، و 0.4 م / ث. أشنارت النتائج إلى تجفيف شـر ائح البصل من محتوى رطوبة 83\% إلى 26٪ محتوى رطوبة على أساس رطب او من 4.88 جم من الماء / جم من المادة الجافة إلى 0.35 جم

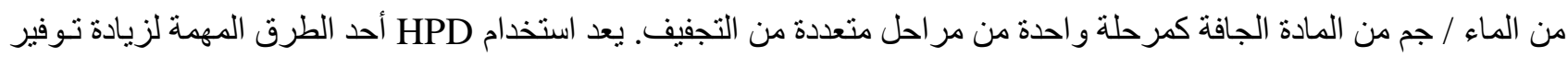
الطاقة في التجفيف. واوضحت النتائج المعملية ان توفير الطاقة الناتج عن اسـتخدام HPD كـان بنسبة 22.2٪. تم الحصـول على أفضل قيمة لـ "R" لمعادلة تغير المحتوى الرطوبي بمرور الوقت لتجفيف شر ائح البصل المصري بواسطة نماذج تجفيف مختلفة لـ (EHD) 